NASA Technical Memorandum 106954

56578

\title{
Effect of Velocity and Temperature Distribution at the Hole Exit on Film Cooling of Turbine Blades
}

Vijay K. Garg

AYT Corporation

Brook Park, Ohio

and

Raymond E. Gaugler

Lewis Research Center

Cleveland, Ohio

Prepared for the

40th Gas Turbine and Aeroengine Congress and Exposition sponsored by the American Society of Mechanical Engineers Houston, Texas, June 5-8, 1995

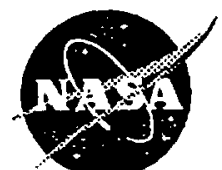

National Aeronautics and Space Administration
(NAJA-TM-106954) EFFECT OF VELOCITY AND TEMPFRATURE

OISTRIBUTION AT THE HOLE EXIT ON

FIL" COGLING OF TURBINE ELADES

(NASA. Lewis Resoarch Canter) $14 \mathrm{p}$
N95-30702

Unclas

$63 / 07$

0056578 


\title{
EFFECT OF VELOCITY AND TEMPERATURE DISTRIBUTION AT THE HOLE EXIT ON FILM COOLING OF TURBINE BLADES
}

\author{
Vijay K. Garg' \\ AYT Corporation \\ Brookpark, $\mathrm{OH}$ \\ Raymond E. Gaugler' \\ Turbomachinery Flow Physics Branch \\ Internal Fluid Mechanics Division \\ NASA Lewis Research Center \\ Mail Stop 5-11, Cleveland, $\mathrm{OH}$
}

\begin{abstract}
An existing three-dimensional Navier-Stokes code (Arnone et al., 1991), modified to include film cooling considerations (Garg and Gaugler, 1994), has been used to study the effect of coolant velocity and temperature distribution at the hole exit on the heat transfer coefficient on three film-cooled turbine blades, namely, the $\mathrm{C} 3 \mathrm{X}$ vane, the $\mathrm{VKI}$ rotor, and the ACE rotor. Results are also compared with the experimental data for all the blades. Moreover, Mayle's transition criterion (Mayle, 1991), Forest's model for augmentation of leading edge heat transfer due to freestream turbulence (Forest, 1977), and Crawford's model for augmentation of eddy viscosity due to film cooling (Crawford et al., 1980) are used. Use of Mayle's and Forest's models is relevant only for the ACE rotor due to the absence of showerhead cooling on this rotor. It is found that, in some cases, the effect of distribution of coolant velocity and temperature at the hole exit can be as much as $60 \%$ on the heat transfer coefficient at the blade suction surface, and $50 \%$ at the pressure surface. Also, different effects are observed on the pressure and suction surface depending upon the blade as well as upon the hole shape, conical or cylindrical.
\end{abstract}

\section{NOMENCLATURE}

$a, b$ semi-axes of the ellipse describing the hole exit on the blade surface

$a_{n}-a_{3}$ coefficients in equation (1)

$B_{r} \quad$ blowing ratio $\left[=\left(\rho_{c} V_{c}\right) /\left(\rho_{\infty} U_{\infty}\right)\right]$

c true chord of the blade

$\mathrm{C}_{\mathrm{F}} \quad$ coefficient in equation (2)

d coolant hole diameter

h heat transfer coefficient based on $\left(T_{0}-T_{w}\right)$

$\mathrm{h}_{\mathrm{o}} \quad$ standard value $\left(=1135.6 \mathrm{~W} / \mathrm{m}^{2}-\mathrm{K}=200 \mathrm{Btu} / \mathrm{hr}-\mathrm{ft}^{2}-\mathrm{R}\right)$

k von Karman constant

$\ell \quad$ mixing length

L length of the injection pipe
M Mach number

p pressure

PD penetration distance (Crawford's model)

r coolant hole radius $(=\mathrm{d} / 2)$

$\operatorname{Re}$ Reynolds number based on the true chord length

$s$ distance from the leading edge along the pressure or suction surface

$s_{0}, z_{0}$ coordinates of the center of hole exit on the blade surface $T$ temperature

Tu turbulent intensity

U main-flow velocity

$\mathrm{V}$ coolant velocity at any point within the hole exit

$x \quad$ streamwise distance from the point of injection

$\mathrm{y}^{+}$dimensionless distance of the first point off the blade surface

$z$ distance along the span

$\delta$ boundary layer thickness

$\varepsilon_{\mathrm{M}} \quad$ eddy diffusivity for momentum

$\gamma$ ratio of specific heats

$\eta, \zeta$ coordinates from the center of hole exit (see equation 1)

$v$ kinematic viscosity

$\rho$ density

$\theta$ momentum thickness

\section{Subscripts}

1 at inlet

2 at exit

c for coolant (average value)

e edge of boundary layer

m maximum value

n corresponding to uncooled blade

- stagnation value

w at the blade surface

$\infty$ local free-stream value

'Fellow ASME 


\section{INTRODUCTION}

There is a growing tendency these days to use higher and higher temperatures at the inlet to a turbine since it yields higher thermal efficiency. Modern gas turbine engines are designed to operate at inlet temperatures of 1800-2000 K, which are far beyond the allowable metal temperatures. Thus, to maintain acceptable life and safety standards, the structural elements need to be protected against the severe thermal loads. This calls for an efficient cooling system. One such cooling technique currently used for high temperature turbines is film cooling. In this technique, cooler air is injected into the high temperature boundary layer on the blade surface. Since the cooler air is bled directly from the compressor before it passes through the combustion chamber, it represents a loss in the total power output. The designer's goal is therefore to minimize the coolant necessary to insure adequate turbine life.

To this end, considerable effort has been devoted into understanding the coolant film behavior and its interaction with the mainstream flow. The film cooling performance is influenced by the wall curvature, three-dimensional external flow structure, free-stream turbulence, compressibility, flow unsteadiness, the hole size, shape and location, and the angle of injection. Many studies on film cooling have been confined to simple geometries, for example, two-dimensional flat and curved plates in steady, incompressible flow. A survey of work up to 1971 has been provided by Goldstein (1971). While several further studies in this field have been summarized by Garg and Gaugler (1993, 1994, 1995), we will discuss some relevant ones here from the point of view of the present study.

Bergeles et al. (1980) devised a finite-difference code with a semi-elliptic treatment of the flow field in the neighborhood of the injection holes. The comparison of predicted results with experimental data on a flat plate showed poor agreement in the vicinity of the hole partly due to the assumption of a uniform coolant velocity at the hole exit. Schönung and Rodi (1987) presented a two-dimensional boundary layer model with a modification for three-dimensional elliptic flow for simulating the effects of film cooling by a single row of holes. The region near the injection was leapt over and new profiles were prescribed at a certain distance behind the blowing region. Later, Haas et al. (1991) extended Schönung and Rodi's (1987) model to account for density differences between the hot gas and the injected coolant gas. However, both the models did not account for the effects of curvature and multiple rows of holes. Tafti and Yavuzkurt (1990) developed a two-dimensional injection model for use with a two-dimensional low-Reynolds number $k-\varepsilon$ model boundary layer code for film cooling applications. They specified a uniform coolant temperature but non-uniform velocity profile at the hole exit. Dibelius et al. (1990) developed an elliptic procedure near the injection area but a partially parabolic procedure far downstream for film cooling on a flat plate. They prescribed a uniform coolant velocity but slightly non-uniform coolant temperature at the hole exit.

Vogel (1991) described a 3-D Navier-Stokes code for filmcooled gas turbine blades that couples the flow problem over the blade with the 3-D heat conduction problem within the blade. Using a uniform coolant velocity at the hole exit, Vogel compared the heat transfer coefficients with experimental data for injection on a flat plate. He could not get reliable results on a turbine blade due to the computer storage limitations that did not allow more than four to six mesh cells within the hole opening on the blade surface. Benz and Wittig (1992) analyzed the elliptic interaction of film-cooling air with the main flow by simultaneously computing the coolant and main flows for film cooling at the leading edge of a turbine blade. They prescribed a uniform coolant flow at entry to the injection pipe, and found a non-uniform velocity profile at the hole exit. They did not provide any information about the temperature field. Amer et al. (1992) compared two forms each of the $k-\varepsilon$ and $k-\omega$ family of turbulence models for film cooling, and found all of them to be inappropriate. Realizing the importance of coolant distribution at the hole exit, they tried a linear, a parabolic and the $1 / 7$ th powerlaw velocity profile for the coolant at the hole exit. Finding only small differences due to the parabolic and power-law profiles, they provided most results using the latter profile.

Dorney and Davis (1993) analyzed the film cooling effectiveness from one and two rows of holes on a turbine vane, using Rai's (1989) numerical technique. They carried out both two- and three-dimensional simulations, but represented each hole by just two grid points, and specified uniform velocity and temperature of the coolant at the hole exit. Choi (1993) developed a multi-zone code for film cooling with a fine mesh near the coolant hole and injection pipe overlapped on the global coarse grid. He specified uniform conditions for the coolant at entry to the injection pipe but provided no details for the coolant profiles at the hole exit. Leylek and Zerkle (1994) analyzed the coupled problem of flow in the plenum, film-hole, and crossstream region for film-cooling on a flat plate using the $k-\varepsilon$ model of turbulence in a 3-D Navier-Stokes code. They found the flow within the film-hole to be extremely complex, containing counterrotating vortices and local jetting effects that make the flow field in this region highly elliptic. The distribution of dependent variables at the hole exit plane resulted from the interaction of three competing mechanisms, namely, counter-rotating structure and local jetting effects within the film-hole, and cross-flow blockage.

Fougeres and Heider (1994) solved the unsteady threedimensional Navier-Stokes equations, completed by a mixinglength turbulence model, using a finite volume technique. They presented two applications of the multi-domain code; one for a single row of hot jets injected into a flat plate turbulent boundary layer, and another for a plane nozzle guide vane with two rows of staggered holes on the pressure as well as suction side of the vane. They specified uniform conditions for the coolant at entry to the injection pipe but provided no details for the coolant profiles at the hole exit. Weigand and Harasgama (1994) carried out a numerical investigation of film cooling on a turbine rotor blade using Dawes (1993) code that utilizes an unstructured solution adaptive grid methodology for solving three-dimensional Navier-Stokes equations. They discretized the plenum chamber and the injection pipe. However, a rather academic case of blowing in tangential direction was studied due to limitations of the code. As such, comparison with experimental data was not possible.

Hall et al. (1994) analyzed the shower-head film cooling on the $\mathrm{C} 3 \mathrm{X}$ vane with a multi-block, three-dimensional Navier-Stokes code using the Baldwin-Lomax turbulence model. Taking advantage of the spanwise periodicity of the planar $C 3 X$ vane, the 
computational span was restricted to just one spanwise pitch of the shower-head holes. The final airfoil C-grid had over 2.1 million grid points with a $17 \times 17$ grid patch on each of the five holes. Such a grid refinement cannot be handled by present day computers if the vane were annular requiring the whole span to be analyzed, not just a slice of it. The computational domain included the injection pipe but not the plenum chamber. They specified uniform coolant conditions at entry to the injection pipe but provided no details of the coolant distribution at the hole exit.

The above survey indicates that the effect of coolant distribution at the hole exit, though important, has not yet been investigated on real turbine blades. This is precisely the objective of the present study. Herein, an existing three-dimensional Navier-Stokes code (Amone et al., 1991), modified to include film cooling considerations (Garg and Gaugler, 1994), has been used to study the effect of coolant velocity and temperature profiles at the hole exit on the heat transfer characteristics of filmcooled turbine blades. Comparison with experimental data for a C3X vane with nine rows of film cooling holes (Hylton et al., 1988), for a VKI rotor with six rows of holes (Camci and Arts, 1990), and for the ACE rotor with three rows of holes (Norton et al., 1990), is provided.

\section{ANALYSIS}

The three-dimensional Navier-Stokes code of Amone et al. (1991) for the analysis of turbomachinery flows was modified by Garg and Gaugler (1994) to include film cooling effects and Mayle's transition criterion (Mayle, 1991). It was further modified to include Forest's model for augmentation of leading edge heat transfer due to free-stream turbulence (Forest, 1977), and Crawford's model for augmentation of eddy viscosity due to film cooling (Crawford et al,, 1980). Briefly, the code is an explicit, multigrid, cell-centered, finite volume code with an algebraic turbulence model. The Navier-Stokes equations in a rotating Cartesian coordinate system are mapped onto a general body-fitted coordinate system using standard techniques. Viscous effects in the streamwise direction are neglected in comparison to those in the other two directions. Justification for this assumption is provided in Garg and Gaugler (1994). The multistage RungeKutta scheme developed by Jameson et al. (1981) is used to advance the flow solution in time from an initial guess to the steady state. A spatially varying time step along with a CFL number of 5 was used to speed convergence to the steady state. Eigenvalue-scaled artificial dissipation and variable-coefficient implicit residual smoothing are used along with a full-multigrid method.

The effects of film cooling have been incorporated into the code in the form of appropriate boundary conditions at the hole locations on the blade surface. Each hole exit (generally an ellipse with semi-axes $a$ and $b$ in the plane of the blade surface) is represented by several control volumes (about 20 ) having a total area equal to the area of the hole exit, and passing the same coolant mass flow. Different velocity and temperature profiles for the injected gas can be specified at the hole exit. Earlier studies indicate that typical gas turbine film cooling situations involve steep polynomial profiles with their maxima shifted in upstream or downstream direction from the jet centerline. Based on a detailed computation through the plenum chamber and injection pipe, Leylek and Zerkle (1994) found that for high $\mathrm{L} / \mathrm{d}(\geq 3.0)$ and high blowing ratio ( $\geq 1.0$ ) or for low $\mathrm{L} / \mathrm{d}$ and low blowing ratio, the exit velocity profile is very much like a fully developed turbulent pipe flow profile. For other combinations of $\mathrm{L} / \mathrm{d}$ and blowing ratio, Leylek and Zerkle (1994) found that the exit velocity profile is polynomial with shifted maxima. For the cases reported here, turbulent ( $1 / 7$ th power-law) and polynomial profiles of the form

$$
\frac{V}{V_{c}}=a_{3} \frac{T-T_{w}}{T_{c}-T_{w}}=\left(1-\eta^{2}-\zeta^{2}\right)\left(a_{0}+a_{1} \eta+a_{2} \eta^{2}\right)
$$

where

$$
\eta=\left(s-s_{0}\right) / a, \quad \zeta=\left(z-z_{0}\right) / b
$$

were specified, in order to study their effect on the heat transfer coefficient at the blade surface. Note that equation (1) automatically satisfies $\mathrm{V}=0$ condition on the boundary of the hole exit, and in it $\left(s_{o}, z_{n}\right)$ denotes the center of hole exit, and $\eta$ and $\zeta$ are interchangeable. Using the coolant mass conservation condition, coefficients $a_{n}, a_{1}, a_{2}$ can be related to $V_{m}$, the maximum value of $V$ and its location, $V_{*}$ Then using the coolant energy conservation, $a_{3}$ can be related to the other coefficients. These relations are

$$
\begin{gathered}
a_{2}=\frac{1}{1+6 V_{l}^{2}}\left[12-\frac{6 V_{m}\left(1-3 V_{l}^{2}\right)}{\left(1-V_{l}^{2}\right)^{2}}\right], \\
a_{1}=\frac{2 V_{l} V_{m}}{\left(1-V_{l}^{2}\right)^{2}}-2 a_{2} V_{l}, \quad a_{0}=2-a_{2} / 6, \\
a_{3}=a_{0}^{2} / 3+\left(a_{1}^{2}+2 a_{0} a_{2}\right) / 24+a_{2}^{2} / 80
\end{gathered}
$$

For all the three blades analyzed here, the experimentally determined temperatures were specified at the blade surface, and wall heat flux was calculated. The algebraic mixing length turbulence model of Baldwin and Lomax (1978) was used. This model has been used satisfactorily by Boyle and Giel (1992), Ameri and Amone (1994a, b), and Boyle and Ameri (1994) for heat transfer calculations on turbine blades without film cooling, and by Hall et al. (1994), and Garg and Gaugler (1994) with film cooling. In fact, Ameri and Amone (1994b) compared the Baldwin-Lomax model and Coakley's $q-\omega$ model against experimental data of Graziani et al. (1980), and found that the algebraic model was able to produce many of the flow features better than the two-equation model. They further state that this conclusion is strengthened when one takes into account the relative economy of computations with the algebraic model.

Moreover, Mayle's transition criterion (Mayle, 1991) has been implemented in the code. The in-coming flow in the experimental tests on the ACE rotor (Norton et al., 1990) had a turbulence intensity of $4.0 \%$, and it is assumed constant for application of Mayle's model. For the C3X vane and the VKI rotor, Mayle's criterion is immaterial since the flow turns turbulent at the leading edge itself due to shower-head injection.

\subsection{Forest's Model}

The strong favorable free-stream pressure gradients near the 
leading edge result in laminar flow, even with high free-stream turbulence. The laminar heat transfer at the leading edge is, however, increased by the free-stream turbulence. The model of Forest (1977) was incorporated in order to account for this increase. According to this model

$$
\epsilon_{M}=C_{F} l T u_{-} U_{-}
$$

where the mixing length, $\ell$, is defined as

$$
\ell=\min (k y, 0.088)
$$

While several ways to calculate the boundary layer thickness were tried following Davis et al. (1988), it was found that the best method was to relate it to the momentum thickness whose calculation is described later on. The coefficient $C_{F}$ is found from

$$
C_{F}=\frac{0.75}{1+0.04 / \lambda \mid}
$$

where

$$
\lambda=\frac{\theta^{2}}{v} \frac{d U_{e}}{d s}
$$

The momentum thickness is calculated using Thwaites' method, as given by White (1974). According to this, the momentum thickness at a location $s_{1}$ along the blade surface is given by

$$
\theta^{2}\left(s_{1}\right)=\frac{0.45 v}{U_{c}^{6}\left(s_{1}\right)} \int_{0}^{s_{1}} U_{e}^{5} d s
$$

The origin in this calculation is taken as the geometric stagnation point. The above calculation of $\varepsilon_{M}$ due to free-stream turbulence was carried out only when the flow was laminar. Otherwise, the analysis would give significantly increased heat transfer for fully turbulent flow (Boyle, 1991). For the cases analyzed here, it implies that Forest's model is used only for the ACE rotor since for both the VKI rotor and the C3X vane, the flow is turbulent at the leading edge itself due to the shower-head injection.

\subsection{Crawford's Model}

Crawford's model for augmentation of eddy viscosity due to film cooling (Crawford et al., 1980) was developed for use in a two-dimensional boundary layer code to predict heat transfer in full-coverage film cooling situations on flat surfaces. Though not really applicable to the situation, it was used by Stepka and Gaugler (1983) to compare the predicted Stanton numbers with the experimental data for rows of film-cooling holes around the circumference of a cylinder in crossflow. In the absence of a better model, we adopted it also for the present calculations. According to this model, the eddy diffusivity for momentum in the presence of film cooling is modeled by algebraically augmenting the Prandtl mixing length using

$$
\frac{l}{8}=\left(\frac{l}{8}\right)_{3-D}+\left(\frac{l}{8}\right)_{0}
$$

where the "3-D" subscript refers to the 3-D mixing length from the Baldwin and Lomax model, and the "a" denotes the departure due to jet-boundary layer interaction, given by

$$
\begin{aligned}
& \left(\frac{l}{8}\right)_{a}=\lambda_{\max , a} \cdot F \cdot f, \\
& F=2.718\left(\frac{y}{P D}\right)^{2} \exp \left[-\left(\frac{y}{P D}\right)^{2}\right], \\
& f=\exp [-(x / \delta) / 2], \\
& \lambda_{\operatorname{mexa}}=0.0353 \exp \left(2.65 B_{r}\right) \text { for slant angled injection } \\
& \lambda_{\operatorname{maxa}}=0.0177 \exp \left(2.64 B_{r}\right) \text { for compound angled injec } \\
& \lambda_{\operatorname{maxa}}=0.0601 \exp \left(3.46 B_{r}\right) \text { for normal injection }
\end{aligned}
$$

where $x$ is the streamwise distance measured from the point of injection, and PD is the penetration distance. While Crawford's model is essentially two-dimensional, we extended it to three dimensions by linearly augmenting the eddy viscosity in the spanwise direction between holes.

\section{BLADES AND EXPERIMENTAL DETAILS}

The experimental data on the $\mathrm{C} 3 \mathrm{X}$ vane has been provided by Hylton et al. (1988). Figure 1 shows the $\mathrm{C} 3 \mathrm{X}$ vane with the film cooling hole details. The test vane was internally cooled by an array of ten radial cooling holes (not shown in Fig. 1) in the active part of the vane. No heat transfer measurements were made in the actual film-cooled nose piece of the vane as it was thermally isolated from the rest of the vane. In addition to the details available in Fig. 1, the two rows of holes on the pressure surface were located at $s / s_{m}=0.197,0.225$, and on the suction surface at $s / s_{m}=0.254,0.276$. One row of shower-head holes was located at the geometric leading edge, with one row on the suction side and three on the pressure side. The active part of the test vane surface was instrumented with $1230.51 \mathrm{~mm}$ diameter sheathed CA thermocouples to measure the temperature at the blade surface. The thermocouple junctions were located in a plane $2.54 \mathrm{~mm}$ off mid-span. The heat transfer coefficient for each radial cooling hole was calculated from the hole diameter, measured coolant flow rate, and coolant temperature with a correction applied for thermal entry region effects. The internal temperature field of the test vane was obtained from a finite element solution of the steady state heat conduction equation, using the measured surface temperatures as boundary conditions. Experimental values of the heat flux at the blade surface were then obtained from the normal temperature gradient at the blade surface, and these were used to derive the local heat transfer coefficient at a spanwise location $2.54 \mathrm{~mm}$ off the mid-span of the blade. More details are available in Hylton et al. (1988).

The experimental data on the VKI rotor has been provided by Camci and Arts (1990), using the short-duration VKI Isentropic Compression Tube facility. Figure 2 shows the VKI rotor geometry along with cooling hole details. Three staggered rows of cylindrical cooling holes $(d=0.8 \mathrm{~mm} ; \mathrm{s} / \mathrm{c}=-0.0285,0$, 
0.0285 ) were located around the leading edge. The row and hole spacings were respectively 2.28 and $2.48 \mathrm{~mm}$. These holes were spanwise angled at $30^{\circ}$ from the tangential direction and drilled in a plane perpendicular to the blade surface. Two staggered rows of conical holes $(d=0.8 \mathrm{~mm} ; s / c=0.206,0.237)$ were located on the suction side. The row and hole spacings were respectively 2.48 and $2.64 \mathrm{~mm}$. These holes were inclined at $37^{\circ}$ and $43^{\circ}$ with respect to the local blade surface and drilled in a plane perpendicular to the span. One row of conical holes $(d=0.8 \mathrm{~mm}$; $\mathrm{s} / \mathrm{c}=-0.315$ ) was located along the pressure side. The hole spacing was $2.64 \mathrm{~mm}$. These holes were inclined at $35^{\circ}$ with respect to the local blade surface and drilled in a plane perpendicular to the span. The blade instrumented for heat flux measurements was milled from 'Macor' glass ceramic and 45 platinum thin films were applied on its surface. Three independent cavities were drilled along the blade height to act as plenum chambers. The local wall convective heat flux was deduced from the corresponding time-dependent surface temperature evolution, provided by the platinum thin-film gages. The wall temperature/wall heat flux conversion was obtained from an electrical analogy, simulating a one-dimensional semi-infinite body configuration. More details are available in Camci and Arts (1990).

The experimental data on the ACE rotor has been provided by Norton et al. (1990), using the Isentropic Light Piston Tunnel at Oxford University. The blade profile tested was the mid-height streamline section of a highly loaded, transonic, research turbine rotor. Build $X$ of the $A C E$ rotor, shown in Fig. 3, was used for comparison purposes. In this, one row of cylindrical holes $(d=$ $0.65 \mathrm{~mm} ; \mathrm{s} / \mathrm{s}_{\mathrm{m}}=0.7$ ) was located on the suction surface, with a hole spacing of $4 \mathrm{~d}$. Two staggered rows of cylindrical holes (d $=0.65 \mathrm{~mm} ; \mathrm{s} / \mathrm{s}_{\mathrm{m}}=0.5,0.56$ ) were located on the pressure surface, with a row and hole spacing of $4 \mathrm{~d}$ each. All holes were inclined $30^{\circ}$ to the local blade surface and drilled in a plane perpendicular to the span. The instrumented blades were manufactured from 'Macor' glass ceramic onto which were placed thin film platinum resistance thermometers and pads. The heat transfer measurement technique is similar to that used by Camci and Arts (1990). More details are available in Norton et al. (1990).

\section{COMPUTATIONAL DETAILS}

For all the blades, the computational span, shown in Fig. 4, is different from the real span. The ordinate in each part of Fig. 4 denotes the distance along the blade surface in the spanwise direction, while the abscissa denotes the distance along the blade surface in the chordwise direction, both normalized by the hole radius, r. For the VKI rotor, the hole spacing in the span direction was assumed to be $2.56 \mathrm{~mm}(=6.4 \mathrm{r}$ ) for all holes, representing a deviation of $\pm 3 \%$ from the actual values of 2.48 and $2.64 \mathrm{~mm}$. It may be noted that the abscissa in Fig. 4 has breaks so as to accommodate all the rows of holes. The shape and orientation of the hole openings in Fig. 4 is a direct consequence of the angles the holes make with the spanwise or chordwise direction. For all the blades, the pattern of holes shown in Fig. 4 is repeated in the spanwise direction. For the $\mathrm{C} 3 \mathrm{X}$ vane and the VKI rotor, periodic boundary conditions are imposed due to shower-head injection, while for the ACE rotor, symmetry conditions are imposed on the ends of the computational span.
Since the hole diameter on all the blades is less than $1 \mathrm{~mm}$, the grid size has to be varied along the blade chord. For computational accuracy, the ratio of two adjacent grid sizes in any direction was kept within 0.76 to 1.3. A periodic C-grid with up to one million grid points was used. For the $C 3 X$ vane, the grid used was $281 \times 45 \times 81$, while for the VKI and ACE rotors, it was $353 \times 53 \times 17$ and $313 \times 53 \times 17$, respectively, where the first number represents the number of grid points along the main flow direction, the second in the blade-to-blade direction, and the third in the span direction. Normal to the blade surface is the dense viscous grid, with $\mathrm{y}^{+}<1$ for the first point off the blade surface, following Boyle and Giel (1992). Computations were run on the 8-processor Cray Y-MP supercomputer at the NASA Lewis Research Center, and on the 16-processor C-90 supercomputer at NASA Ames Research Center. The code requires about 60 million words $(\mathrm{Mw})$ of storage and takes about 20 seconds per iteration (full-multigrid) on the C-90 machine for one million grid points. For a given grid the first case requires about 1100 iterations to converge, while subsequent cases for the same grid require about 300 iterations starting with the solution for the previous case.

\section{RESULTS AND DISCUSSION}

Three experimental cases for the C3X vane, three for the VKJ rotor and two for the ACE rotor were analyzed for comparison. The values of various parameters for these cases are given in Table 1. In this table, the derived film cooling parameters are based upon the assumption of one-dimensional compressible flow through the hole. For the $\mathrm{C} 3 \mathrm{X}$ vane, cases 44135 and 44155 represent the minimum and maximum blowing ratio, respectively, for the shower-head holes, while the case 44355 represents the warmest coolant. For the VKI rotor, case number is designated by the ratio of coolant mass to the main-flow mass; the main difference between the $3.09 \%$ and $3.32 \%$ cases being the colder coolant for the latter. For the ACE rotor, case 6115 represents about half the blowing ratio for the case 6109 . In all cases except case 6115 for the ACE rotor, the blowing ratio is high $\left(B_{r} \geq 1.0\right)$.

Figure 5 shows the coolant velocity and temperature profiles at the hole exit, effect of which was studied on the heat transfer coefficient at various blade surfaces. The profiles shown in Fig. 5 are at the centerline through the hole, with the abscissa covering the hole. Clearly, the $1 / 7$ th power law profile does not satisfy the zero gradient condition at the centerline. The polynomial profile shown is for $V_{m}=2.449=$ twice the maximum velocity for the $1 / 7$ th power law profile, and $V_{1}=0$. It was found, however, that results for the heat transfer coefficient corresponding to the polynomial profile did not change more than $-5 \%$ for $-0.4 \leq \mathrm{V}$, $\leq 0.4$.

We now present results for the three blades separately. Figure 6 shows the non-uniform experimentally determined temperature on the $\mathrm{C} 3 \mathrm{X}$ vane surface for the three cases. These temperature values were specified as the boundary condition for the blade surface temperature in the code as well. In this and later figures, except Figs. 10-12, s represents the normalized distance along the pressure or suction surface of the blade. Besides the somewhat erratic temperature variation over $|s|>0.25$, caused by the internal cooling holes (not shown in Fig. 1) in the active part of the blade, there is a sharp drop in temperature at each end of the insulated portion of the blade $(|s| \approx 0.25)$. 
Figures 7-9 provide the effect of coolant velocity and temperature distribution at the hole exit on the normalized heat transfer coefficient (solid and dash curves) at the blade surface in comparison with experimental data (Hylton et al., 1988), denoted by $\square$, for the cases 44135,44155 and 44355 , respectively, at a spanwise location (near mid-span) where the experimental data was taken. The heat transfer coefficient values in these figures have been normalized with respect to an arbitrary value, $h_{0}=$ $1135.6 \mathrm{~kW} / \mathrm{m}^{2}-\mathrm{K}$, as per Hylton et al. (1988). There is no data given for about $25 \%$ of surface length on either side of the leading edge since this portion contained the plenum chambers for injection of the colder gas and was insulated from the rest of the blade in the experimental tests (cf. Fig. 1). The fluctuations in the data are due to the non-uniform blade surface temperature in the experimental data. The nine short vertical lines near the center-bottom of these figures denote the location of film cooling rows. For all three cases the normalized heat transfer coefficient corresponding to the polynomial profiles of coolant velocity and temperature at the hole exit is about $50-60 \%$ higher than that corresponding to the $1 / 7$ th power law over most of the suction surface. However, the difference over the pressure surface is only about $\pm 10 \%$ for the case 44135 (Fig. 7), about $\pm 20 \%$ for the case 44155 (Fig. 8), and about 35\% for the case 44355 (Fig. 9). Also, the $1 / 7$ th power law profile results seem to match better with the experimental data than the polynomial profile results for all the cases.

For the $\mathrm{C} 3 \mathrm{X}$ vane, we may point out that experimentally, the heat flux on the blade (inner) surface was calculated from a finite element analysis of conduction within the blade, and the heat transfer coefficient was then found by dividing this heat flux by $\left(T_{n}-T_{w}\right)$. The present study computes the heat transfer coefficients on the blade (outer) surface from the threedimensional Navier-Stokes analysis. Also, the uncertainty in the heat transfer coefficient measurement varies from about $10 \%$ near $|s|=0.3$ to about $22 \%$ near $|s|=0.95$ (Hylton et al., 1988).

Let us now turn to the comparison of results for the VKI rotor. For this rotor, the blade was specified to be isothermal with $T_{w} / T_{0}$ $=0.7$. Figures 10-12 display the effect of coolant velocity and temperature distribution at the hole exit on the normalized heat transfer coefficient (solid and dash curves) at the blade surface in comparison with experimental data (Camci and Arts, 1990), denoted by $\square$, for the three cases at mid-span. In these figures, $h_{n}$ corresponds to the heat transfer coefficient at an uncooled blade surface. Also, the abscissa represents the surface distance along the blade normalized by the true chord, in conformity with the available experimental data (Camci and Arts, 1990). The six short vertical lines in the center-bottom of these figures denote the location of film cooling rows. From these figures we find, in contrast to the results for the $\mathrm{C} 3 \mathrm{X}$ vane, that the differences in $\mathrm{h} / \mathrm{h}$ values corresponding to the two coolant profiles at the hole exit are negligible over most of the suction surface and considerable (about 30\%) over the pressure surface. The heat transfer coefficient corresponding to the polynomial profiles of coolant injection is generally larger than that corresponding to the $1 / 7$ th power law profiles. Also, comparison with experimental data is fair for either of the coolant profiles results. The experimental uncertainty in the measurement of heat transfer coefficient is about 5\% except in the shower-head region where it is estimated to be as high as 10-15\% (Camci and Arts, 1990).
Due to normalization with respect to $h_{n}$, however, each experimental data point represents two measurements, one for the cooled and another for the uncooled blade. The same is true for the computations as well, and may be the reason for the relatively good comparison with the experimental data for the VKI rotor in contrast to that for the $\mathrm{C} 3 \mathrm{X}$ vane in Figs. 7-9. We may also point out that the suction and pressure surface holes on the VKI rotor are conical while the shower-head holes on the VKI rotor as well as all holes on the $\mathrm{C} 3 \mathrm{X}$ vane are cylindrical. This may account for the relatively smaller effect of coolant velocity and temperature distribution at the hole exit on the heat transfer coefficient at the $\mathrm{VKI}$ rotor surface in contrast to that for the $\mathrm{C} 3 \mathrm{X}$ vane.

We now turn to the discussion of results for the ACE rotor. Figure 13 shows the non-uniform experimentally determined temperature on the ACE rotor surface for the two cases analyzed. These temperature values were specified as the boundary condition for the blade surface temperature in the code as well. Figures 14 and 15 show the effect of coolant velocity and temperature distribution at the hole exit on the heat transfer coefficient (solid and dash curves) at the blade surface in comparison with experimental data (Norton et al., 1990), denoted by $\square$, for the two cases at mid-span. The short vertical lines in these figures as well as Fig. 16 denote the location of film cooling rows. Due to the absence of shower-head cooling, this is the only case where Mayle's transition criterion and Forest's model for augmentation of laminar heat transfer at the leading edge due to free-stream turbulence are useful. Clearly, both models seem to be effective in yielding results that compare well with the experimental data. While the effect of coolant profiles at the hole exit is negligible for the low blowing ratio case 6115 in Fig. 14, it is considerable (as much as $50 \%$ higher $h$ corresponding to the polynomial profile) over the pressure surface for the high blowing ratio case 6109 in Fig. 15. For both cases, however, effect on the suction surface is negligible, in conformity with the results for the $\mathrm{VKI}$ rotor but in direct contrast to those for the $\mathrm{C} 3 \mathrm{X}$ vane. The polynomial profile for the coolant velocity and temperature distribution at the hole exit results in a very good comparison with the experimental data downstream of the cooling holes on the pressure surface in Fig. 15. Norton et al. (1990) could not get such a good comparison on the pressure surface; their prediction is similar to ours for the $1 / 7$ th power law profile.

Figure 16 shows the effect of Crawford's model on the heat transfer coefficient at the ACE rotor surface for the case 6109 . The results in Fig. 16 correspond to the polynomial profiles for coolant velocity and temperature at the hole exit. Clearly, the effect of Crawford's model is felt only within the region of holes; it is negligible downstream of the holes. We may note that due to the absence of shower-head cooling, the flow upstream of the holes is essentially two-dimensional (no spanwise variation) for the ACE rotor.

\section{CONCLUSIONS}

A three-dimensional Navier-Stokes code has been used to study the effect of coolant velocity and temperature distribution at the hole exit on the heat transfer coefficient on three film-cooled turbine blades, namely, the $\mathrm{C} 3 \mathrm{X}$ vane, the VKI rotor, and the $A C E$ rotor. Results are also compared with the experimental data for all the blades. Moreover, Mayle's transition criterion (Mayle, 
1991), Forest's model for augmentation of leading edge heat transfer due to free-stream turbulence (Forest, 1977), and Crawford's model for augmentation of eddy viscosity due to film cooling (Crawford et al., 1980) are used. It is found that different velocity and temperature distributions of coolant at the hole exit can lead to as much as a $60 \%$ change in the heat transfer coefficient at the blade surface in some cases. Also, different effects are observed on the pressure and suction surface depending upon the blade as well as upon the hole shape, conical or cylindrical. Thus specification of proper conditions at the hole exit is important in film-cooling applications. This calls for a detailed analysis of the in-hole and near-hole physics under conditions relevant to the gas turbine.

\section{ACKNOWLEDGEMENTS}

This work was done when the first author held a National Research Council - NASA Research Associateship at the NASA Lewis Research Center. Helpful discussions with A.A. Ameri and R.J. Boyle of the NASA Lewis Research Center are gratefully acknowledged.

\section{REFERENCES}

Amer, A.A., Jubran, B.A. and Hamdan, M.A., 1992 , "Comparison of Different Two-Equation Turbulence Models for Prediction of Film Cooling from Two Rows of Holes," Numer. Heat Transfer, Vol. 21, Part A, pp. 143-162.

Ameri, A.A. and Amone, A., 1994a, "Transition Modeling Effects on Turbine Rotor Blade Heat Transfer Predictions," ASME Paper 94-GT-22.

Ameri, A.A. and Arnone, A., 1994b, "Prediction of Turbine Blade Passage Heat Transfer Using a Zero and a Two-Equation Turbulence Model," ASME Paper 94-GT-122.

Arnone, A., Liou, M.-S. and Povinelli, L.A., 1991, "Multigrid Calculation of Three-Dimensional Viscous Cascade Flows," AIAA Paper 91-3238.

Baldwin, B.S. and Lomax, H., 1978, "Thin-Layer Approximation and Algebraic Model for Separated Turbulent Flows," AIAA Paper 78-257.

Benz, E. and Wittig, S., 1992, "Prediction of the Interaction of Coolant Ejection with the Main Stream at the Leading Edge of a Turbine Blade: Attached Grid Application," Proc. Intl. Symp. Heat Transfer in Turbomachinery, Athens, Greece.

Bergeles, G., Gosman, A.D. and Launder, B.E., 1980, "DoubleRow Discrete-Hole Cooling: an Experimental and Numerical Study," J. Eng. Power, Vol. 102, pp. 498-503.

Boyle, R.J., 1991, "Navier-Stokes Analysis of Turbine Blade Heat Transfer," J. Turbomachinery, Vol. 113, pp. 392-403.

Boyle, R.J. and Ameri, A.A., 1994, "Grid Orthogonality Effects on Predicted Turbine Midspan Heat Transfer and Performance," ASME Paper 94-GT-123.

Boyle, R.J. and Giel, P., 1992, "Three-Dimensional Navier Stokes Heat Transfer Predictions for Turbine Blade Rows," AIAA Paper 92-3068.

Camci, C. and Arts, T., 1990, "An Experimental Convective Heat Transfer Investigation Around a Film-Cooled Gas Turbine Blade," J. Turbomachinery, Vol. 112, pp. 497-503.

Choi, D., 1993, "A Navier-Stokes Analysis of Film Cooling in a Turbine Blade," AIAA Paper 93-0158.

Crawford, M.E., Kays, W.M. and Moffat, R.J., 1980, "Full-
Coverage Film Cooling on Flat, Isothermal Surfaces: A Summary Report on Data and Predictions," NASA CR 3219.

Davis, R.L., Hobbs, D.E. and Weingold, H.D., 1988, "Prediction of Compressor Cascade Performance Using a NavierStokes Technique," J. Turbomachinery, Vol. 110, pp. 520-531.

Dawes, W.N., 1993, "The Extension of a Solution-Adaptive Three-Dimensional Navier-Stokes Solver Toward Geometries of Arbitrary Complexity," J. Turbomachinery, Vol. 115, pp. 283-295.

Dibelius, G.H., Pitt, R. and Wen, B., 1990, "Numerical Prediction of Film Cooling Effectiveness and the Associated Aerodynamic Losses with a Three-Dimensional Calculation Procedure," ASME Paper 90-GT-226.

Dorney, D.J. and Davis, R.L., 1993, "Numerical Simulation of Turbine Hot Spot Alleviation Using Film Cooling," J. Propul. Power, Vol. 9, pp. 329-336.

Forest, A.E., 1977, "Engineering Predictions of Transitional Boundary Layers," AGARD-CP-224.

Fougeres, J.M. and Heider, R., 1994, "Three-Dimensional Navier-Stokes Prediction of Heat Transfer with Film Cooling," ASME Paper 94-GT-14.

Garg, V.K. and Gaugler, R.E., 1993, "Heat Transfer in FilmCooled Turbine Blades," ASME Paper 93-GT-81.

Garg, V.K. and Gaugler, R.E., 1994, "Prediction of Film Cooling on Gas Turbine Airfoils," ASME Paper 94-GT-16.

Garg, V.K. and Gaugler, R.E., 1995, "Leading Edge Film Cooling Effects on Turbine Blade Heat Transfer," ASME Paper 95-GT-275.

Goldstein, R.J., 1971, "Film Cooling," Advances in Heat Transfer, Vol. 7, pp. 321-379.

Graziani, R.A., Blair, M.F., Taylor, J.R. and Mayle, R.E., 1980, "An Experimental Study of Endwall and Airfoil Surface Heat Transfer in a Large Scale Turbine Blade Cascade," J. Eng. Power, Vol. 102, pp. 257-267.

Haas, W., Rodi, W. and Schönung, B., 1991, "The Influence of Density Difference Between Hot and Coolant Gas on Film Cooling by a Row of Holes: Predictions and Experiments," ASME Paper 91-GT-255.

Hall, E.J., Topp, D.A. and Delaney, R.A., 1994, "Aerodynamic/Heat Transfer Analysis of Discrete Site FilmCooled Turbine Airfoils," AIAA Paper 94-3070.

Hylton, L.D., Nirmalan, V., Sultanian, B.K. and Kaufman, R.M., 1988, "The Effects of Leading Edge and Downstream Film Cooling on Turbine Vane Heat Transfer," NASA CR 182133.

Jameson, A., Schmidt, W. and Turkel, E., 1981, "Numerical Solutions of the Euler Equations by Finite Volume Methods Using Runge-Kutta Time-Stepping Schemes," AIAA Paper 81-1259.

Leylek, J.H. and Zerkle, R.D., 1994, "Discrete-Jet Film Cooling: A Comparison of Computational Results With Experiments," J. Turbomachinery, Vol. 116, pp. 358-368.

Mayle, R.E., 1991, "The Role of Laminar-Turbulent Transition in Gas Turbine Engines," J. Turbomachinery, Vol. 113, pp. 509537.

Norton, R.J.G., Forest, A.E., White, A.J., Henshaw, D.G., Epstein, A.H., Schultz, D.L. and Oldfield, M.L.G., 1990, "Turbine Cooling System Design, Vol. I and III," WRDC-TR-89-2109.

Rai, M.M., 1989, "Three-Dimensional Navier-Stokes Simulations of Turbine Rotor-Stator Interaction; Part I Methodology," AIAA J. Propul. \& Power, Vol. 5, pp. 305-311. Schönung, B. and Rodi, W., 1987, "Prediction of Film Cooling 
by a Row of Holes with a Two-Dimensional Boundary-Layer Procedure," J. Turbomachinery, Vol. 109, pp. 579-587.

Stepka, F.S. and Gaugler, R.E., 1983, "Comparison of Predicted and Experimental External Heat Transfer Around a Film Cooled Cylinder in Crossflow," ASME Paper 83-GT-47.

Tafti, D.K. and Yavuzkurt, S., 1990, "Prediction of Heat Transfer Characteristics for Discrete Hole Film Cooling for Turbine Blade Applications," J. Turbomachinery, Vol. 112, pp. 504-511.
Vogel, T., 1991, "Computation of 3-D Viscous Flow and Heat Transfer for the Application to Film Cooled Gas Turbine Blades," Paper 7, AGARD-CP-510.

Weigand, B. and Harasgama, S.P., 1994, "Computations of a Film Cooled Turbine Rotor Blade with Non-Uniform Inlet Temperature Distribution Using a Three-Dimensional Viscous Procedure," ASME Paper 94-GT-15.

White, F.M., 1974, "Viscous Fluid Flow," McGraw-Hill, New York.

TABLE 1 PARAMETER VALUES FOR THE CASES ANALYZED

Main Flow Parameters (Experimental)

\begin{tabular}{|c|c|c|c|c|c|c|c|c||}
\hline Blade & Case & $\mathrm{P}_{o}\left(\mathrm{kN} / \mathrm{m}^{2}\right)$ & $\mathrm{T}_{\mathrm{o}}(\mathrm{K})$ & $\mathrm{M}_{1}$ & $\mathrm{Re}_{1}$ & $\mathrm{M}_{2}$ & $\mathrm{Re}_{2}$ & $\mathrm{Tu}$ \\
\hline $\mathrm{C} 3 \mathrm{X}$ & 44135 & 281.55 & 705 & 0.20 & $6.2 \times 10^{5}$ & 0.90 & $2.0 \times 10^{6}$ & $6.5 \%$ \\
\hline $\mathrm{C} 3 \mathrm{X}$ & 44155 & 280.95 & 705 & 0.19 & $6.0 \times 10^{5}$ & 0.90 & $2.0 \times 10^{6}$ & $6.5 \%$ \\
\hline $\mathrm{C} 3 \mathrm{X}$ & 44355 & 284.02 & 702 & 0.18 & $5.6 \times 10^{5}$ & 0.90 & $2.02 \times 10^{6}$ & $6.5 \%$ \\
\hline $\mathrm{VKI}$ & all & 290.00 & 415 & 0.25 & - & 0.925 & $2.32 \times 10^{6}$ & $5.2 \%$ \\
\hline $\mathrm{ACE}$ & 6115 & 286.22 & 463 & 0.396 & $5.5 \times 10^{5}$ & 1.196 & $1.01 \times 10^{6}$ & $4.0 \%$ \\
\hline $\mathrm{ACE}$ & 6109 & 238.83 & 402 & 0.39 & $5.4 \times 10^{5}$ & 1.182 & $1.01 \times 10^{6}$ & $4.0 \%$ \\
\hline
\end{tabular}

Film Cooling Parameters (Derived)

\begin{tabular}{|c|c|c|c|c|c|c|c||}
\hline \multirow{2}{*}{ Blade } & \multirow{2}{*}{ Case } & \multicolumn{3}{|c|}{$\left(\rho_{c} \mathrm{~V}_{c} \gamma^{1 / 2}\right) /\left(\rho_{0} c_{n}\right)$} & \multicolumn{3}{c|}{$T_{c} T_{\mathrm{o}}$} \\
\cline { 3 - 8 } & & $\begin{array}{c}\text { Shower } \\
\text { Head }\end{array}$ & $\begin{array}{c}\text { Suction } \\
\text { Surface }\end{array}$ & $\begin{array}{c}\text { Pressure } \\
\text { Surface }\end{array}$ & $\begin{array}{c}\text { Shower } \\
\text { Head }\end{array}$ & $\begin{array}{c}\text { Suction } \\
\text { Surface }\end{array}$ & $\begin{array}{c}\text { Pressure } \\
\text { Surface }\end{array}$ \\
\hline C3X & 44135 & 0.20 & 0.634 & 0.426 & 0.745 & 0.558 & 0.668 \\
\hline C3X & 44155 & 0.411 & 0.639 & 0.427 & 0.7 & 0.55 & 0.667 \\
\hline C3X & 44355 & 0.366 & 0.564 & 0.387 & 0.826 & 0.7 & 0.803 \\
\hline VKI & $2.07 \%$ & $.092-.13$ & $.176, .182$ & 0.231 & $.657-.666$ & 0.645 & 0.623 \\
\hline VKI & $3.09 \%$ & $.166-.237$ & $.224, .233$ & 0.314 & $.609-.618$ & 0.623 & 0.584 \\
\hline VKI & $3.32 \%$ & $.175-.249$ & .239 .248 & 0.352 & $.491-.499$ & 0.497 & 0.449 \\
\hline ACE & 6115 & 0.0 & 0.314 & $.18, .20$ & - & 0.514 & 0.62 \\
\hline ACE & 6109 & 0.0 & 0.635 & $.37, .41$ & - & 0.595 & $.695,7$ \\
\hline
\end{tabular}


2 ROWS OF HOLBS

$35^{\circ}$ ANGLE CHORDWISE

3d SPANWISE SPACING

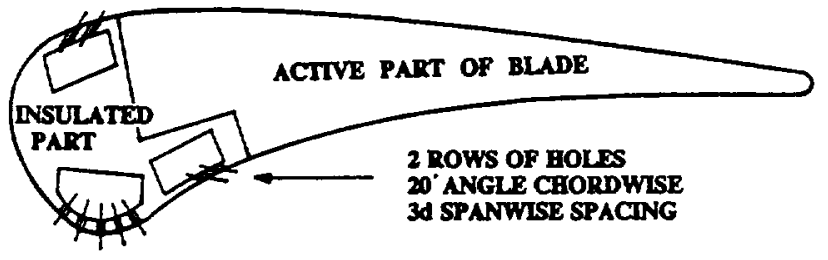

5 ROWS OF STAGGERED HOLES

45. ANGLE SPANWTSE

7.Sd SPANWLE SPACING

HOLE DU. $d=0.99 \mathrm{~mm}$

4d ROW SPACING

HOLES NORMAL TO DLRECTION UNSPECIFLED

FIG. 1 C3X VANE AND COOLING HOLE DETAILS.
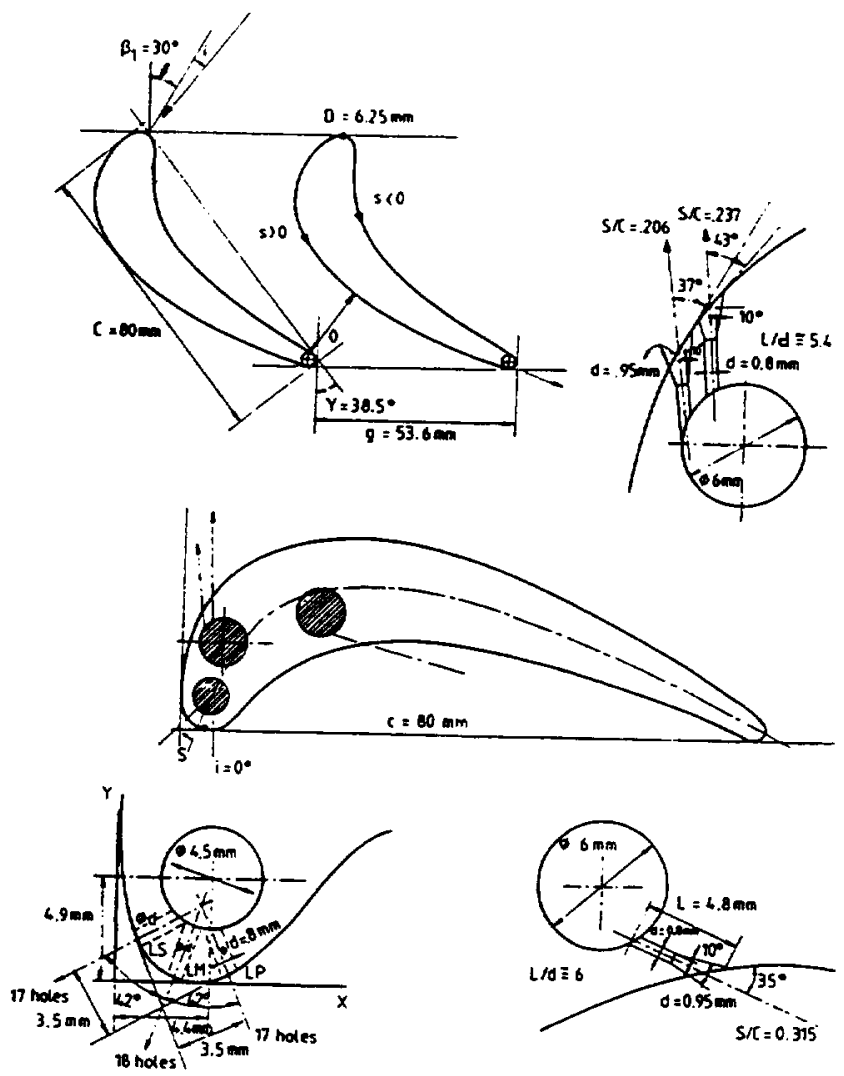

FIG. 2 VKI ROTOR AND COOLING HOLE DETAILS.

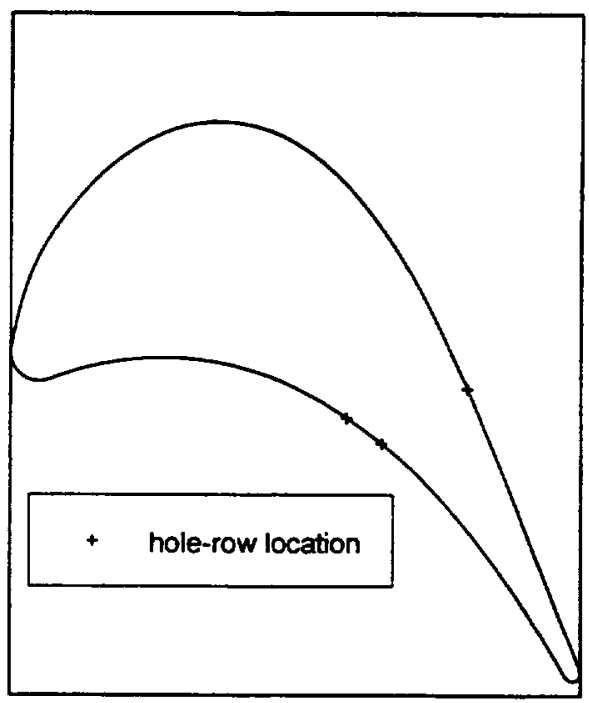

FIG. 3 ACE ROTOR AND COOLING HOLE LOCATIONS.
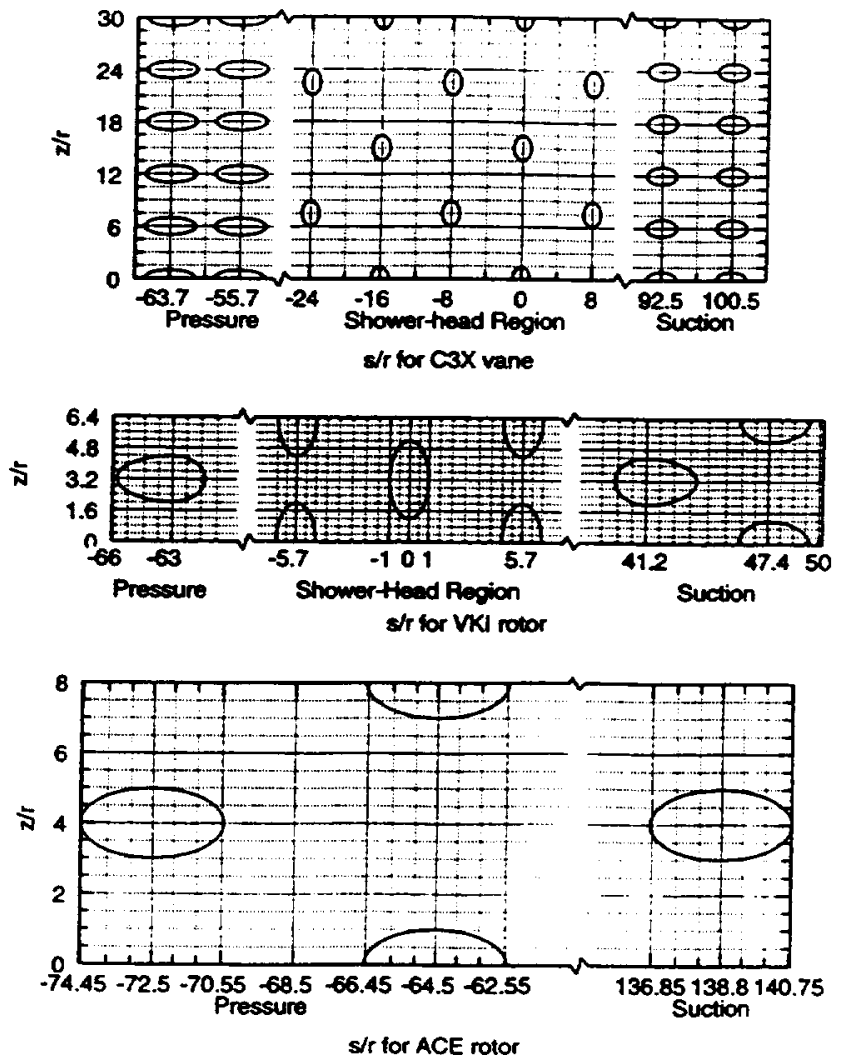

FIG. 4 COMPUTATIONAL SPAN FOR THE C3X VANE, VKI ROTOR AND THE ACE ROTOR. 


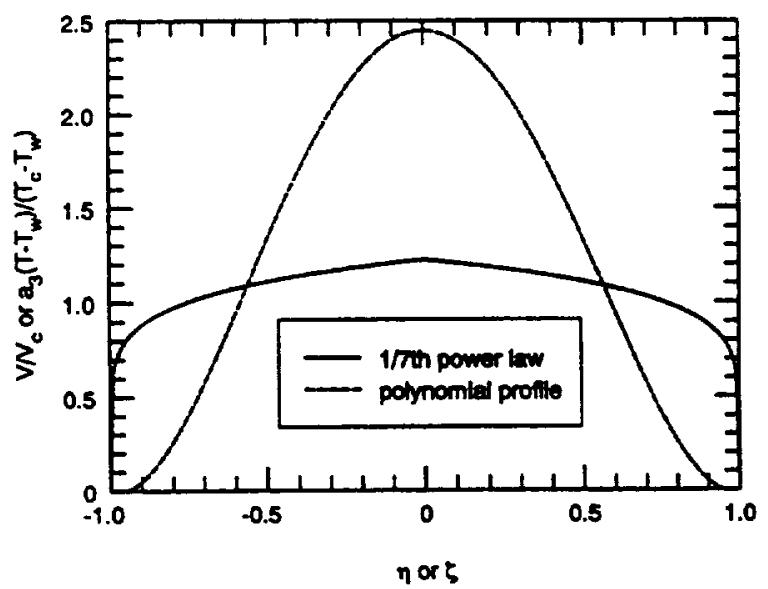

FIG. 5 COOLANT VELOCITY AND TEMPERATURE PROFILES AT THE HOLE EXIT.

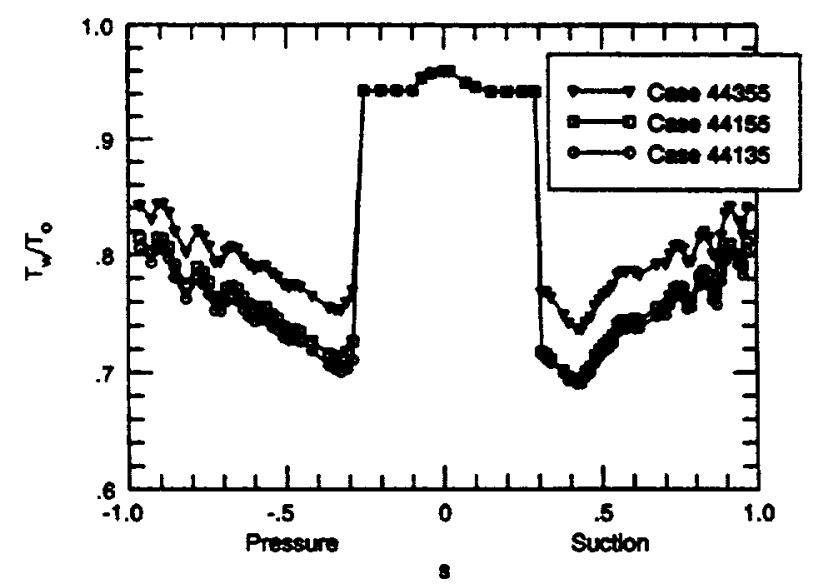

FIG. 6 BLADE SURFACE TEMPERATURE FOR VARIOUS CASES (C3X VANE).

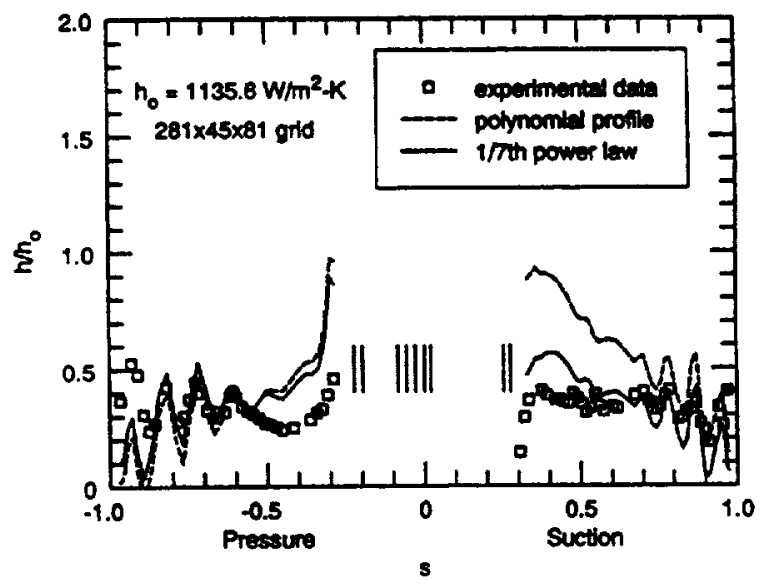

FIG. 7 EFFECT OF COOLANT VELOCITY AND TEMPERATURE PROFILES ON THE NORMALIZED HEAT TRANSFER COEFFICIENT AT THE C3X VANE SURFACE (CASE 44135).

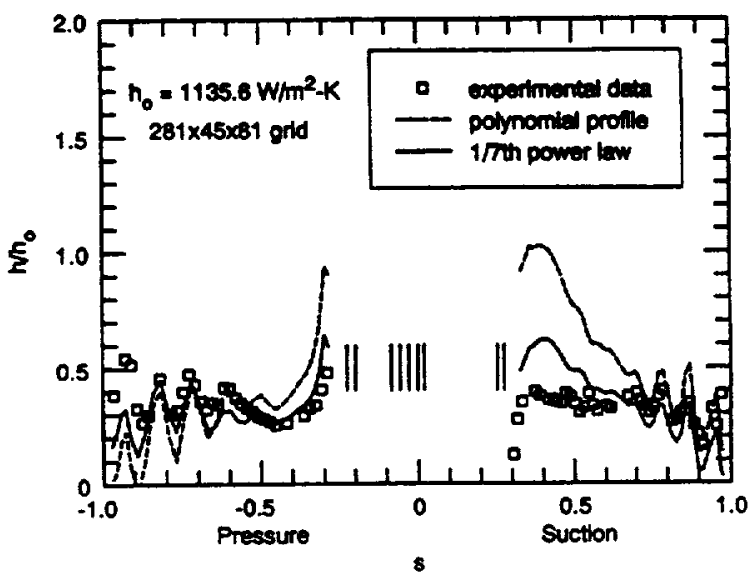

FIG. 8 EFFECT OF COOLANT VELOCITY AND TEMPERATURE PROFILES ON THE NORMALIZED HEAT TRANSFER COEFFICIENT AT THE C3X VANE SURFACE (CASE 44155). 


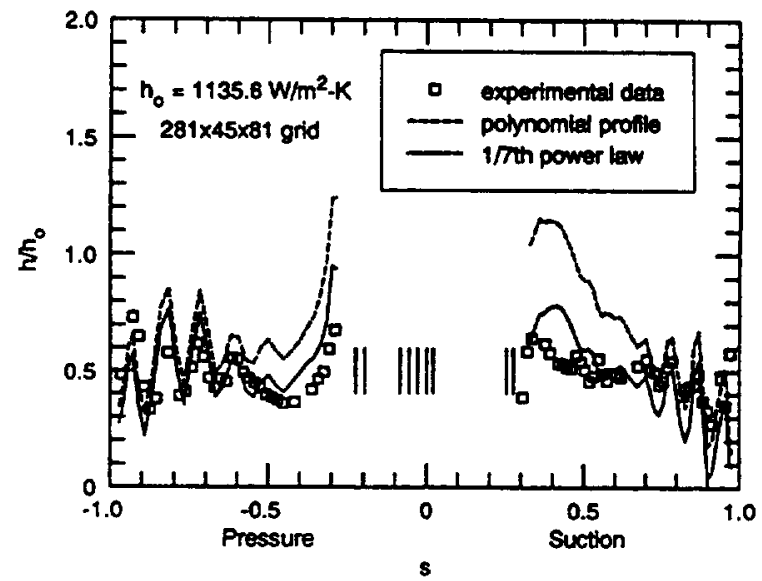

FIG. 9 EFFECT OF COOLANT VELOCITY AND TEMPERATURE PROFILES ON THE NORMALIZED HEAT TRANSFER COEFFICIENT AT THE C3X VANE SURFACE (CASE 44355).

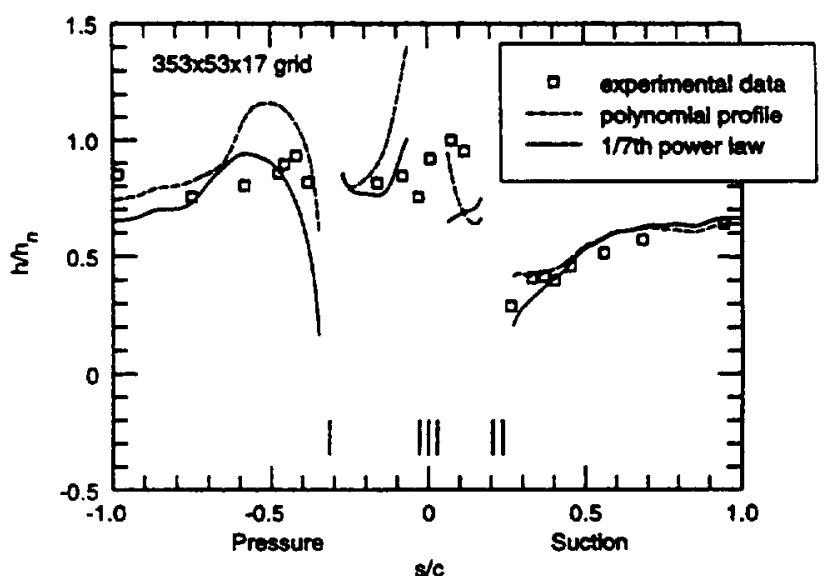

FIG. 10 EFFECT OF COOLANT VELOCITY AND TEMPERATURE PROFILES ON THE NORMALZED HEAT TRANSFER COEFFICIENT AT THE VKI ROTOR SURFACE $(2.07 \%$ COOLANT CASE).

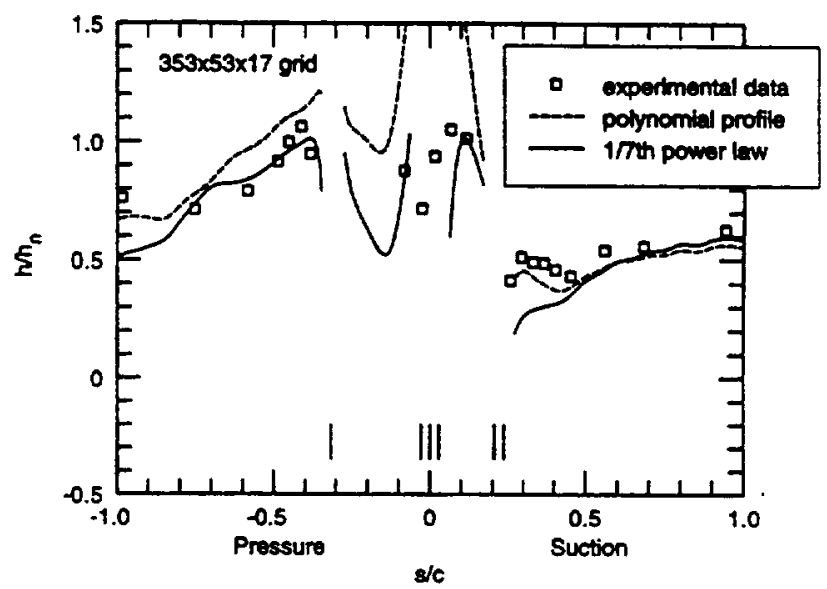

FIG. 11 EFFECT OF COOLANT VELOCITY AND TEMPERATURE PROFILES ON THE NORMALIZED HEAT TRANSFER COEFFICIENT AT THE VKI ROTOR SURFACE $(3.09 \%$ COOLANT CASE).

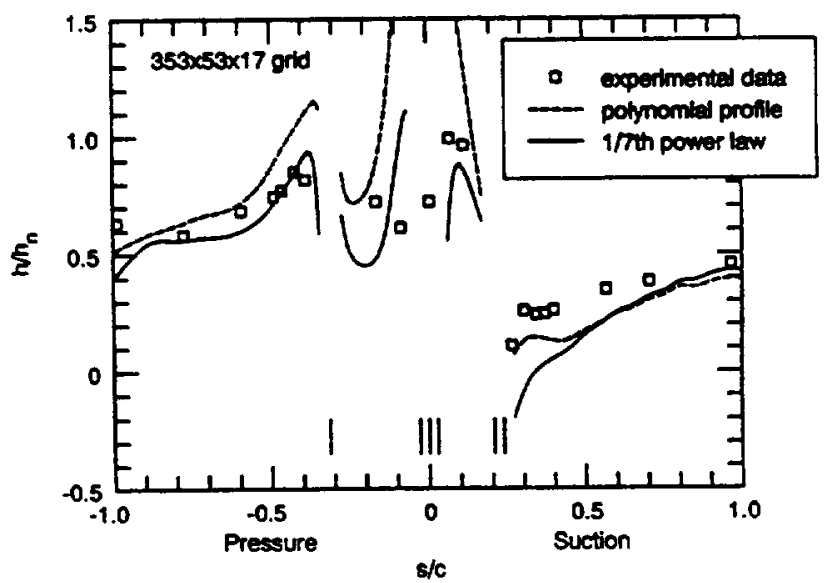

FIG. 12 EFFECT OF COOLANT VELOCITY AND TEMPERATURE PROFILES ON THE NORMALIZED HEAT TRANSFER COEFFICIENT AT THE VKI ROTOR SURFACE $(3.32 \%$ COOLANT CASE). 


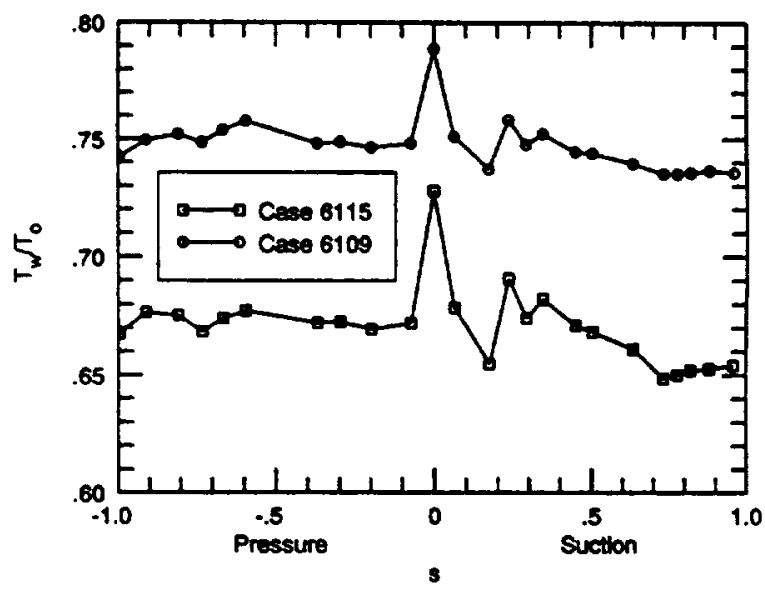

FIG. 13 BLADE SURFACE TEMPERATURE FOR THE TWO CASES (ACE ROTOR).

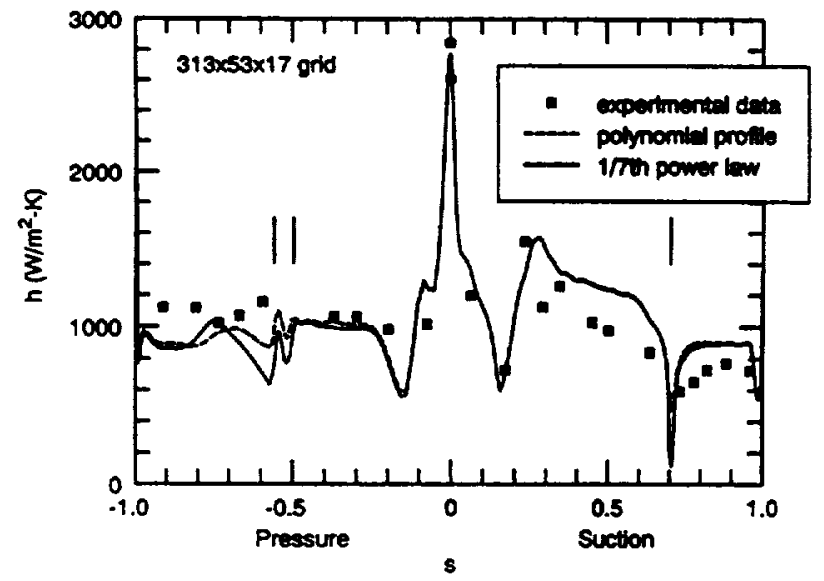

FIG. 14 EFFECT OF COOLANT VELOCITY AND TEMPERATURE PROFILES ON THE HEAT TRANSFER COEFFICIENT AT THE ACE ROTOR SURFACE (CASE 6115).

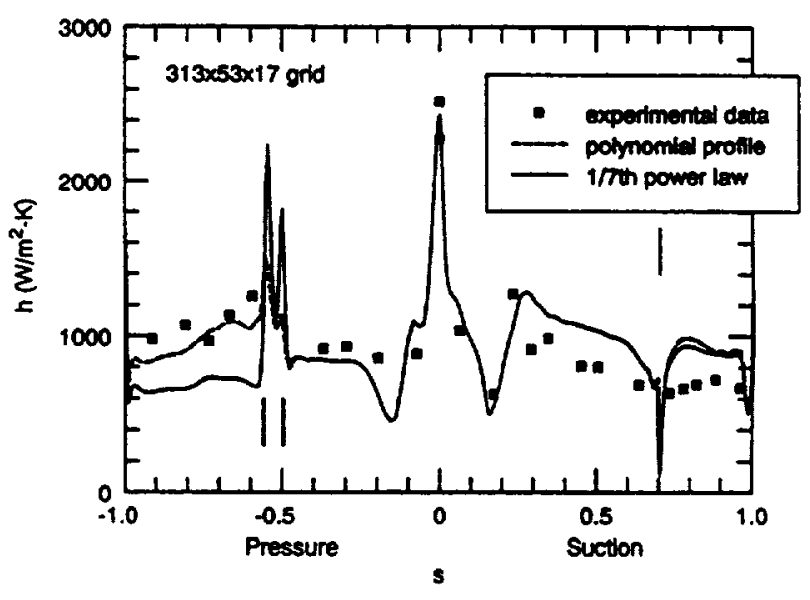

FIG. 15 EFFECT OF COOLANT VELOCITY AND TEMPERATURE PROFILES ON THE HEAT TRANSFER COEFFICIENT AT THE ACE ROTOR SURFACE (CASE 6109).

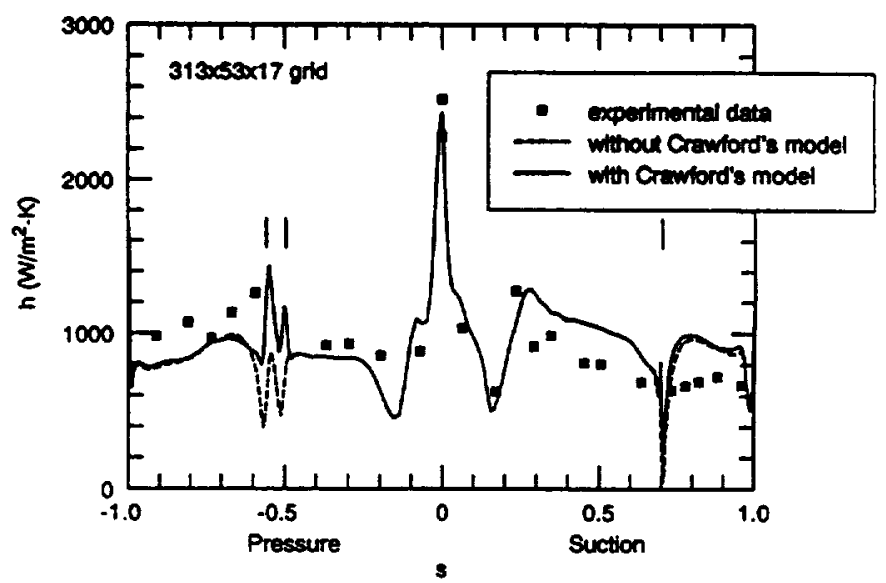

FIG. 16 EFFECT OF CRAWFORD'S MODEL ON THE HEAT TRANSFER COEFFICIENT AT THE ACE ROTOR SURFACE (CASE 6109). 


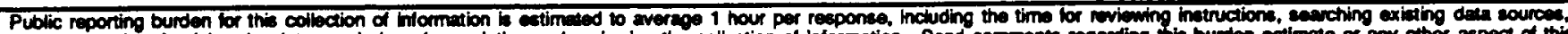

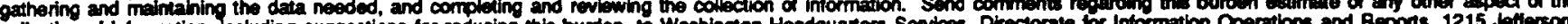

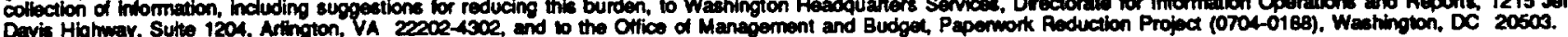

\begin{tabular}{|l|l|l}
\hline 1. AGENCY USE ONLY (Leave blank) & $\begin{array}{c}\text { 2. REPORT DATE } \\
\text { June } 1995\end{array}$ & $\begin{array}{r}\text { 3. REPOAT TYPE AND DATES COVEAED } \\
\text { Technical Memorandum }\end{array}$
\end{tabular}

\section{TITE AND SUBTIIL}

5. FUNDING NUMBERS

Effect of Velocity and Temperature Distribution at the Hole Exit on Film Cooling of Turbine Blades

6. AUTHOR(S)

WU-505-62-52

Vijay K. Garg and Raymond E. Gaugler

7. PERFOAMING ORGANIZATION NAME(S) AND ADDRESS(ES)

8. PERFORMING ORGANIZATION PEPORT NUMBER

National Aeronautics and Space Administration

Lewis Research Center

Cleveland, Ohio 44135-3191

E-9704

9. SPONSORINGMONITORING AGENCY NAME(S) AND ADDRESS(ES)

National Aeronautics and Space Administration

Washington, D.C. 20546-0001

10. SPONSORINGANONTTORING AGENCY REPORT NUMBER

NASA TM-106954

11. SUPPLEMENTARY NOTES

Prepared for the 40th Gas Turbine and Aeroengine Congress and Exposition sponsored by the American Society of Mechanical Engineers, Houston, Texas, June 5-8, 1995. Vijay K. Garg, AYT Corporation, Brook Park, Ohio 44142 and Raymond E. Gaugler, NASA Lewis Research Center. Responsible person, Raymond E. Gaugler, organization code 2640, (210) 433-5882.

\begin{tabular}{l|l|l} 
12a. DISTRIBUTIONAVALABILTY STATEMENT & 12b. DISTRIBUTION CODE
\end{tabular}

Unclassified - Unlimited

Subject Category 07

This publication is available from the NASA Center for Aerospace Information, (301) 621-0390.

13. ABSTRACT (Riaximum 200 words)

An existing three-dimensional Navier-Stokes code (Arnone et al., 1991), modified to include film cooling considerations (Garg and Gaugler, 1994), has been used to study the effect of coolant velocity and temperature distribution at the hole exit on the heat transfer coefficient on three film-cooled turbine blades, namely, the C3X vane, the VKI rotor, and the ACE rotor. Results are also compared with the experimental data for all the blades. Moreover, Mayle's transition criterion (Mayle, 1991), Forest's model for augmentation of leading edge heat transfer due to freestream turbulence (Forest, 1977), and Crawford's model for augmentation of eddy viscosity due to film cooling (Crawford et al., 1980) are used. Use of Mayle's and Forest's models is relevant only for the ACE rotor due to the absence of showerhead cooling on this rotor. It is found that, in some cases, the effect of distribution of coolant velocity and temperature at the hole exit can be as much as $60 \%$ on the heat transfer coeffecient at the blade suction surface, and $50 \%$ at the pressure surface. Also, different effects are observed on the pressure and suction surface depending upon the blade as well as upon the hole shape, conical or cylindrical.

14. SUBJECT TERMS

Film cooling; Turbine; Heat transfer 15. NUMBER OF PAGES

14

\begin{tabular}{c|c|c|}
\hline $\begin{array}{c}\text { 17. SECURTY CLASSIFICATION } \\
\text { OF REPORT } \\
\text { Unclassified }\end{array}$ & $\begin{array}{c}\text { 18. SECURTY CLASSIFICATION } \\
\text { OF THIS PAGE } \\
\text { Unclassified }\end{array}$ & $\begin{array}{c}\text { 19. SECURTY CLASSIFICATION } \\
\text { OF ABSTRACT } \\
\text { Unclassified }\end{array}$ \\
\hline
\end{tabular}


